\title{
$\beta$-Tricalcium phosphate nanofiber scaffolds with fine unidirectional grains
}

Citation for published version (APA):

Gazquez, G. C., Chen, H., Moroni, L., Boukamp, B. A., \& ten Elshof, J. E. (2017). $\beta$-Tricalcium phosphate nanofiber scaffolds with fine unidirectional grains. Materials Letters, 208, 118-121.

https://doi.org/10.1016/j.matlet.2017.05.038

Document status and date:

Published: 01/12/2017

DOI:

10.1016/j.matlet.2017.05.038

Document Version:

Publisher's PDF, also known as Version of record

Document license:

Taverne

Please check the document version of this publication:

- A submitted manuscript is the version of the article upon submission and before peer-review. There can be important differences between the submitted version and the official published version of record.

People interested in the research are advised to contact the author for the final version of the publication, or visit the DOI to the publisher's website.

- The final author version and the galley proof are versions of the publication after peer review.

- The final published version features the final layout of the paper including the volume, issue and page numbers.

Link to publication

\footnotetext{
General rights rights.

- You may freely distribute the URL identifying the publication in the public portal. please follow below link for the End User Agreement:

www.umlib.nl/taverne-license

Take down policy

If you believe that this document breaches copyright please contact us at:

repository@maastrichtuniversity.nl

providing details and we will investigate your claim.
}

Copyright and moral rights for the publications made accessible in the public portal are retained by the authors and/or other copyright owners and it is a condition of accessing publications that users recognise and abide by the legal requirements associated with these

- Users may download and print one copy of any publication from the public portal for the purpose of private study or research.

- You may not further distribute the material or use it for any profit-making activity or commercial gain

If the publication is distributed under the terms of Article $25 \mathrm{fa}$ of the Dutch Copyright Act, indicated by the "Taverne" license above, 


\title{
$\beta$-Tricalcium phosphate nanofiber scaffolds with fine unidirectional grains
}

\author{
Gerard Cadafalch Gazquez ${ }^{\mathrm{a}}$, Honglin Chen ${ }^{\mathrm{b}}$, Lorenzo Moroni ${ }^{\mathrm{b}}$, Bernard A. Boukamp ${ }^{\mathrm{a}}$, Johan E. ten Elshof ${ }^{\mathrm{a}, *}$ \\ a Inorganic Materials Science, MESA+ Institute for Nanotechnology, University of Twente, P.O. Box 217, 7500 AE Enschede, The Netherlands \\ ${ }^{\mathrm{b}}$ Department of Complex Tissue Regeneration, MERLN Institute for Technology Inspired Regenerative Medicine, 6200 MD Maastricht, The Netherlands
}

\section{A R T I C L E I N F O}

\section{Article history:}

Received 8 February 2017

Received in revised form 13 March 2017

Accepted 6 May 2017

Available online 8 May 2017

\section{Keywords}

TCP

Electrospinning

Nanofiber

Grain size

Microstructure

\begin{abstract}
A B S T R A C T
$\beta$-Tricalcium phosphate (TCP) is an osteoinductive and resorbable material that offers superior biochemical activity for bone regeneration therapies. TCP nanofiber scaffolds are particularly promising owing to their high porosity and chemical composition that resemble the mineral phase of natural extracellular matrix. TCP nanofiber scaffolds were fabricated by electrospinning. The nanofiber morphology promoted unidirectional grain growth during the sintering stage due to lack of surrounding grains in the other two principal directions. The average fiber diameter after sintering was $100-125 \mathrm{~nm}$, which is the smallest grain size ever reported for TCP.
\end{abstract}

(c) 2017 Elsevier B.V. All rights reserved.

\section{Introduction}

Nanofiber materials show enhanced structural and functional properties compared to bulk materials, and have been applied in catalysis, energy, biomedicine, sensing and electronics [1-4]. In the field of biomedicine, nanofiber materials are widely used as scaffolds for tissue regeneration. Nanofibers are often made by electrospinning, which involves applying a high voltage between a hollow needle that releases a solution and a counter electrode. The electrified solution is dragged into a fiber shape that dries during transport and is collected on the counter electrode.

Bioceramic materials have been extensively used to repair bone defects [5-7]. They offer similar chemical and mechanical properties as bone [8-10]. Bioactive ceramics, e.g. calcium phosphates and bioactive glasses, have been successfully applied $[5,6,11,12]$. The $\beta$-phase of tricalcium phosphate ( $\beta$-TCP) has shown excellent performance as a scaffold for bone regeneration [11-14]. It offers osteogenic induction and is resorbable by the body $[11,14,15]$.

$\beta$-TCP is a much less reported phase than hydroxyapatite (HA) or calcium deficient HA (CaDHA). $\beta$-TCP results from decomposition of CaDHA at high temperature $[14,16]$. CaDHA forms a secondary phase of $\beta$-TCP above $700{ }^{\circ} \mathrm{C}$. $\beta$-TCP is normally sintered above $1050^{\circ} \mathrm{C}$, but such high temperatures induce grain growth [5].

\footnotetext{
* Corresponding author.

E-mail address: j.e.tenelshof@utwente.nl (J.E. ten Elshof).
}

Porous $\beta$-TCP with small grain sizes has superior properties in terms of osteogenic differentiation, inducing bone growth even in soft tissues [12,14,17]. Bioglass [3,18,19] and HA [20,21] nanofibers by electrospinning have been reported. However, to the best of our knowledge no attempt to fabricate $\beta$-TCP nanofibers has been reported. Here, we demonstrate the successful fabrication of $\beta$-TCP nanofibers by electrospinning.

\section{Materials and methods}

TCP was synthetized using an acid-base reaction between calcium nitrate tetrahydrate (Sigma Aldrich) and phosphoric acid (Sigma Aldrich). A $1 \mathrm{M}$ calcium nitrate tetrahydrate solution was prepared in 1:1 vol/vol ethanol:water. A separate $0.67 \mathrm{M}$ phosphoric acid solution was prepared in $4: 1 \mathrm{vol} / \mathrm{vol}$ ethanol:water. The solutions were stabilized by adding a third solution consisting of either (i) acetic acid (HAc, Sigma Aldrich) acting as chelating agent, or (ii) $1: 1 \mathrm{vol} / \mathrm{vol}$ ethanol:water to decrease the ion concentration. The three solutions were mixed in a volume ratio 2:2:1. Polyvinylpyrrolidone (PVP k90; Mw 360,000 g/mol) was added at a concentration of $100 \mathrm{mg} / \mathrm{ml}$ to control the viscosity.

Electrospinning was performed at $25^{\circ} \mathrm{C}$ and relative humidity $30 \%$. The inner diameter of the spinneret was $0.8 \mathrm{~mm}$. The distance between spinneret and $\mathrm{Al}$ collector plate was $17 \mathrm{~cm}$. The flow rate was $0.25-0.6 \mathrm{~mL} / \mathrm{h}$ and the voltage $12-15 \mathrm{kV}$. The samples were annealed in a convection oven (Eurotherm) or in a microwave oven (Milestone MicroSynth) at $950-1300{ }^{\circ} \mathrm{C}$. The dwell time was 

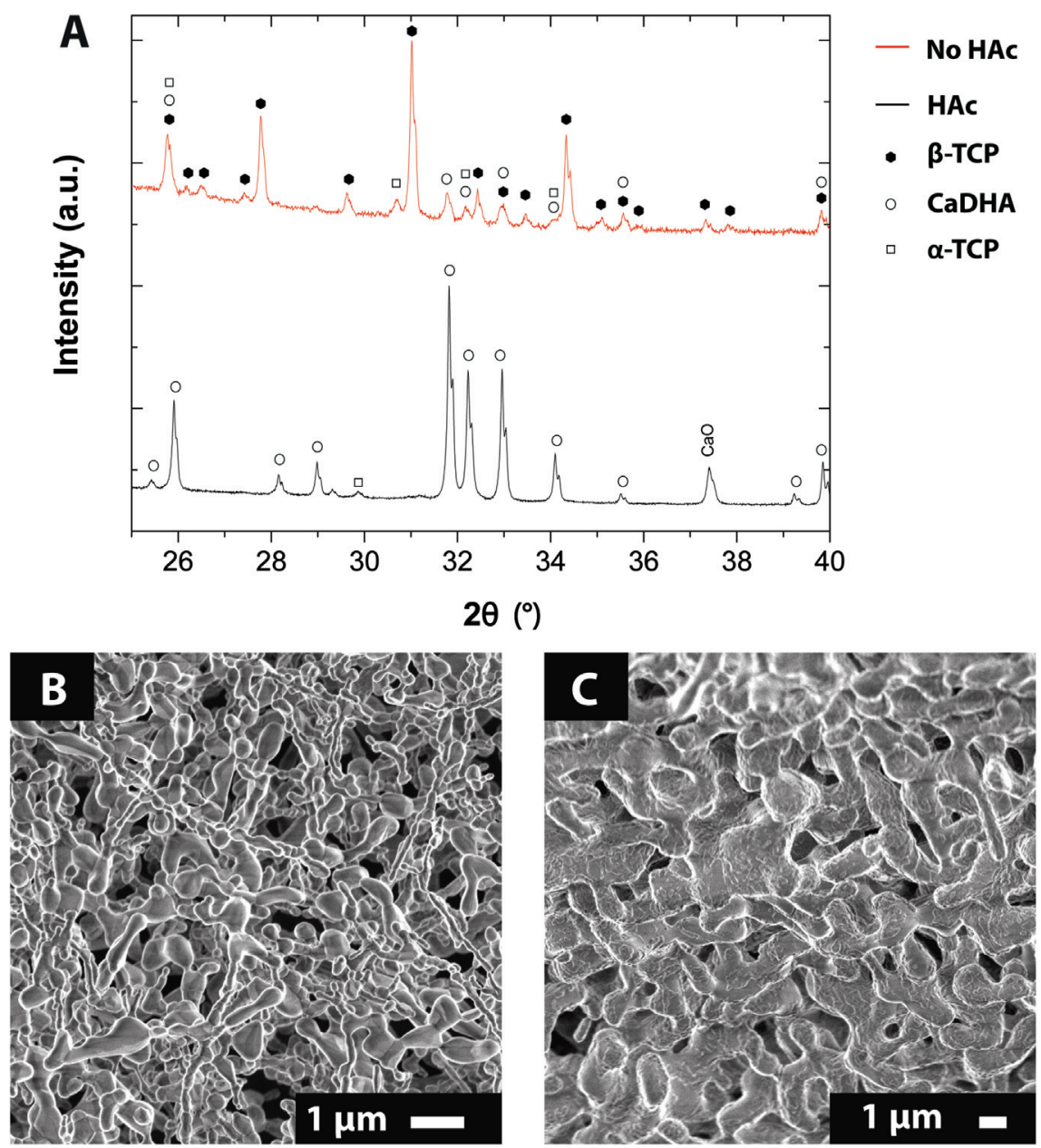

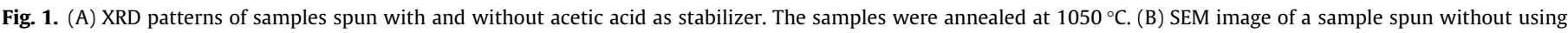
acetic acid and annealed at $1050{ }^{\circ} \mathrm{C}$. (C) SEM image of a sample spun without acetic acid and annealed at $1300{ }^{\circ} \mathrm{C}$. The scale bars are $1 \mu \mathrm{m}$.

$0-1.5 \mathrm{~h}$, using heating and cooling rates of $5-20^{\circ} \mathrm{C} / \mathrm{min}$. A Zeiss Merlin Scanning electron microscope (SEM) was used to investigate the microstructure of the prepared material. A PANalytical X'Pert X-ray Diffraction (XRD) machine was used for phase analysis and grain size determination using the Scherer equation. The XRD data were analyzed with High Score Plus ${ }^{\circledR}$. Fiber diameters and grain sizes were determined by statistical analysis of SEM images.

\section{Results and discussion}

Solutions for electrospinning are normally weak electrolytes with low conductivity [22]. Conductive metal salt solutions as used here require adaptation to limit the effective ionic strength, and facilitate the stability of the electrospinning process. We attempted $\mathrm{HAc}$ as solvent and chelating agent for the metal ions, but a CaDHA phase was obtained instead of $\beta$-TCP (Fig. 1A, bottom). When we used ethanol/water to just dilute the solutions, $\beta$-TCP was formed (Fig. 1A, top). To keep the jet containing non-stabilized ionic charges stable [22], low voltage and flow rate were used.

Sintering of bulk $\beta$-TCP starts above $750^{\circ} \mathrm{C}$, and the highest densities are achieved above $1100{ }^{\circ} \mathrm{C}$ [5]. TCP is usually sintered at temperatures $>1050{ }^{\circ} \mathrm{C}$. However, when we annealed our samples at $1050-1300^{\circ} \mathrm{C}$, the resulting fibers were not continuous due to sintering effects (Fig. 1B,C). The microstructure resembled that of porous CaDHA $[5,23]$. High surface area nanofibers could be formed only at temperatures lower than $1000^{\circ} \mathrm{C}$.
To induce crystallization while avoiding surface area reduction and/or grain growth, short thermal treatments are needed. We thus heated the nanofibers to $950^{\circ} \mathrm{C}$, and then cooled them down immediately with heating/cooling rates of $5-20^{\circ} \mathrm{C} / \mathrm{min}$. In this case only CaDHA fibers were obtained.

When the dwell time was increased to $1.5 \mathrm{~h}, \beta-\mathrm{TCP}$ was obtained as the main phase at $950{ }^{\circ} \mathrm{C}$ (Fig. 2A). However, HA and $\alpha$-TCP secondary phases were also formed, especially in the sample that had been annealed in a convection oven. Similar secondary phases have also been reported in previous studies on TCP formation $[14,16]$. The superior phase purity of the microwave-treated material is attributed to the effect of microwave radiation heating, which may allow better crystallization [24-27].

The samples that were thermally annealed in the microwave oven (Fig. 2B) kept its nanofiber morphology better than the ones annealed in a convection oven (Fig. 2C), which is attributed to the faster heating/cooling rates in the former experiment. The fiber diameters were $120 \pm 20$ and $120 \pm 30 \mathrm{~nm}$, respectively. The grains were approximately $100 \mathrm{~nm}$ wide (Fig. 3), which is close to the fiber diameter. This value is much smaller than normally reported micrometer grain sizes for $\beta$-TCP, and about 2.5 smaller than the smallest reported $\beta$-TCP grain sizes known to us [5]. The grains are anisotropic, directionally oriented along the long axis of the fibers. This is probably caused by the lack of mass transport towards the grain from the surrounding matrix during sintering. 

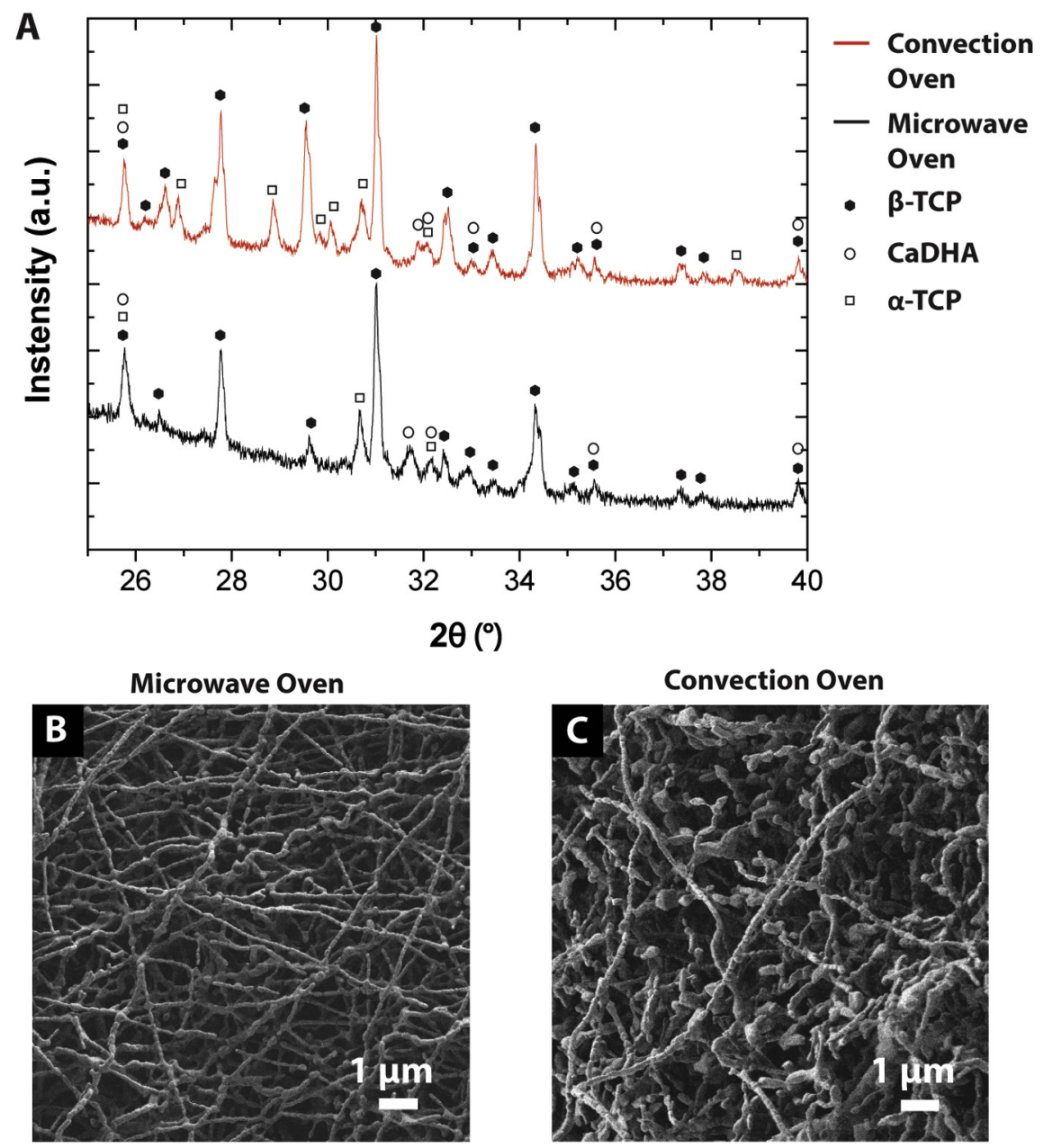

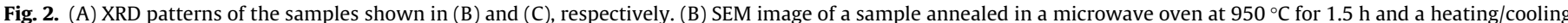

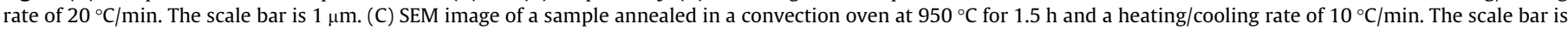
$1 \mu \mathrm{m}$.

\section{Microwave Oven}

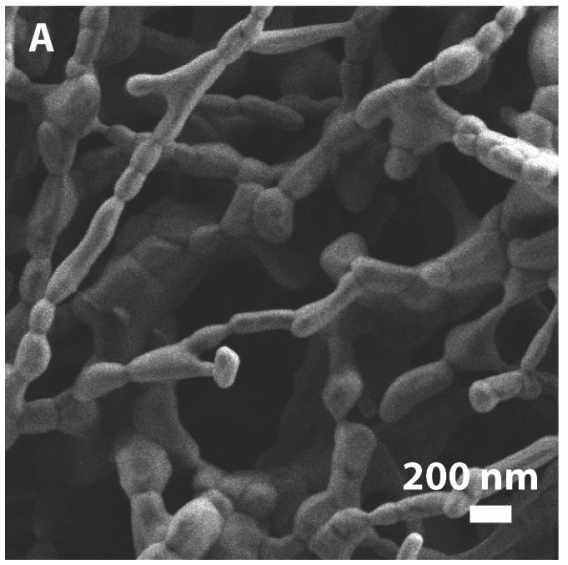

\section{Convection Oven}

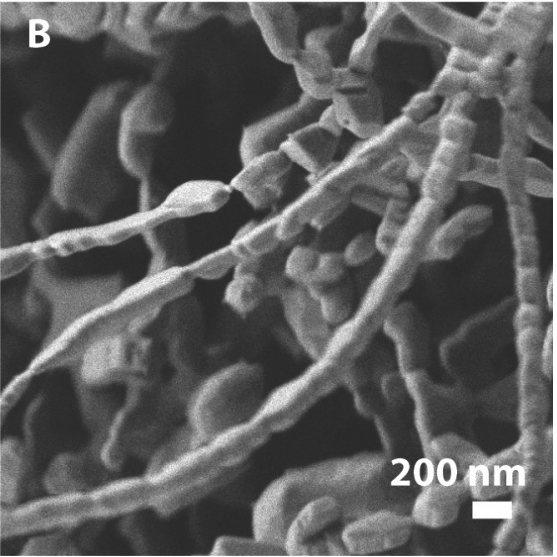

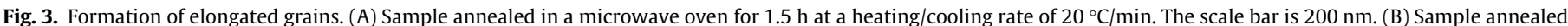
in convection oven for $1.5 \mathrm{~h}$ at a heating/cooling rate of $10^{\circ} \mathrm{C} / \mathrm{min}$. The scale bar is $200 \mathrm{~nm}$.

\section{Conclusions}

$\beta$-TCP nanofiber mats with only a minor fraction of secondary phase were successfully fabricated. The grain sizes were about
$100 \mathrm{~nm}$. Rapid heating/cooling and short sintering times help to maintain small grain sizes. The nanofiber morphology promoted unidirectional grain growth. $\beta$-TCP nanofiber mats may offer an excellent platform for bone regeneration studies. 


\section{Acknowledgements}

Financial support by the ADEM programme is gratefully acknowledged. Honglin Chen thanks the China Council Scholarship program for financial support (Grant \# 2011614016).

\section{References}

[1] H. Wu, W. Pan, D. Lin, H. Li, Electrospinning of ceramic nanofibers: fabrication, assembly and applications, J. Adv. Ceram. 1 (2012) 2-23.

[2] D. Li, J.T. McCann, Y. Xia, M. Marquez, Electrospinning: a simple and versatile technique for producing ceramic nanofibers and nanotubes, J. Am. Ceram. Soc. 89 (2006) 1861-1869.

[3] H.W. Kim, H.E. Kim, J.C. Knowles, Production and potential of bioactive glass nanofibers as a next-generation biomaterial, Adv. Funct. Mater. 16 (2006) 1529-1535.

[4] J.-H. Lee, Y.-J. Kim, Hydroxyapatite nanofibers fabricated through electrospinning and sol-gel process, Ceram. Int. 40 (2014) 3361-3369.

[5] E. Champion, Sintering of calcium phosphate bioceramics, Acta Biomater. 9 (2013) 5855-5875.

[6] S.M. Best, A.E. Porter, E.S. Thian, J. Huang, Bioceramics: past, present and for the future, J. Eur. Ceram. Soc. 28 (2008) 1319-1327.

[7] S.M. Zakaria, S.H. Sharif Zein, M.R. Othman, F. Yang, J.A. Jansen, Nanophase hydroxyapatite as a biomaterial in advanced hard tissue engineering: A review, Tissue Eng. 19 (2013) 431-441.

[8] J.R. Woodard, A.J. Hilldore, S.K. Lan, C.J. Park, A.W. Morgan, J.A.C. Eurell, S.G. Clark, M.B. Wheeler, R.D. Jamison, A.J. Wagoner Johnson, The mechanical properties and osteoconductivity of hydroxyapatite bone scaffolds with multiscale porosity, Biomaterials 28 (2007) 45-54.

[9] V. Karageorgiou, D. Kaplan, Porosity of 3D biomaterial scaffolds and osteogenesis, Biomaterials 26 (2005) 5474-5491.

[10] D.W. Hutmacher, Scaffolds in tissue engineering bone and cartilage, Biomaterials 21 (2000) 2529-2543.

[11] H. Yuan, J.D. De Bruijn, Y. Li, J. Feng, Z. Yang, K. De Groot, X. Zhang, Bone formation induced by calcium phosphate ceramics in soft tissue of dogs: a comparative study between porous $\alpha$-TCP and $\beta$-TCP, J. Mater. Sci. Mater. Med. 12 (2001) 7-13.

[12] H. Yuan, K. Kurashina, J.D. de Bruijn, Y. Li, K. de Groot, X. Zhang, A preliminary study on osteoinduction of two kinds of calcium phosphate ceramics, Biomaterials 20 (1999) 1799-1806.
[13] H. Yuan, Z. Yang, J.D. de Bruijn, K. de Groot, X. Zhang, Material-dependent bone induction by calcium phosphate ceramics: a 2.5-year study in dog, Biomaterials 22 (2001) 2617-2623.

[14] H. Yuan, H. Fernandes, P. Habibovic, J. de Boer, A.M.C. Barradas, A. de Ruiter, W. R. Walsh, C.A. van Blitterswijk, J.D. de Bruijn, Osteoinductive ceramics as a synthetic alternative to autologous bone grafting, Proc. Natl. Acad. Sci. U.S.A. 107 (2010) 13614-13619.

[15] J. Lu, M. Descamps, J. Dejou, G. Koubi, P. Hardouin, J. Lemaitre, J.-P. Proust, The biodegradation mechanism of calcium phosphate biomaterials in bone, J. Biomed. Mater. Res. 63 (2002) 408-412.

[16] G. Cicek, E. Aksoy, C. Durucan, N. Hasirci, Alpha-tricalcium phosphate ( $\alpha-\mathrm{TCP})$ : solid state synthesis from different calcium precursors and the hydraulic reactivity, J. Mater. Sci. Mater. Med. 22 (2011) 809-817.

[17] Y. Kuboki, H. Takita, D. Kobayashi, E. Tsuruga, M. Inoue, M. Murata, N. Nagai, Y. Dohi, H. Ohgushi, BMP-induced osteogenesis on the surface of hydroxyapatite with geometrically feasible and nonfeasible structures: topology of osteogenesis, J. Biomed. Mater. Res. 39 (1998) 190-199.

[18] H. Lu, T. Zhang, X.P. Wang, Q.F. Fang, Electrospun submicron bioactive glass fibers for bone tissue scaffold, J. Mater. Sci. Mater. Med. 20 (2009) 793-798.

[19] W. Xia, D. Zhang, J. Chang, Fabrication and in vitro biomineralization of bioactive glass (BG) nanofibres, Nanotechnology 18 (2007) 135601.

[20] X. Dai, S. Shivkumar, Electrospinning of PVA-calcium phosphate sol precursors for the production of fibrous hydroxyapatite, J. Am. Ceram. Soc. 90 (2007) $1412-1419$.

[21] P.-A. Mouthuy, A. Crossley, H. Ye, Fabrication of calcium phosphate fibres through electrospinning and sintering of hydroxyapatite nanoparticles, Mater. Lett. 106 (2013) 145-150.

[22] G. Collins, J. Federici, Y. Imura, L.H. Catalani, Charge generation, charge transport, and residual charge in the electrospinning of polymers: a review of issues and complications, J. Appl. Phys. 111 (2012) 044701.

[23] P. Habibovic, H. Yuan, C.M. van der Valk, G. Meijer, C.A. van Blitterswijk, K. de Groot, 3D microenvironment as essential element for osteoinduction by biomaterials, Biomaterials 26 (2005) 3565-3575.

[24] J. Wang, J. Binner, B. Vaidhyanathan, N. Joomun, J. Kilner, G. Dimitrakis, T.E. Cross, Evidence for the microwave effect during hybrid sintering, J. Am. Ceram. Soc. 89 (2006) 1977-1984.

[25] R. Wroe, A.T. Rowley, Evidence for a non-thermal microwave effect in the sintering of partially stabilized zirconia, J. Mater. Sci. 31 (1996) 2019-2026.

[26] Z. Xie, J. Yang, X. Huang, Y. Huang, Microwave processing and properties of ceramics with different dielectric loss, J. Eur. Ceram. Soc. 19 (1999) 381-387.

[27] A. Bhaskar, T.H. Chang, H.Y. Chang, S.Y. Cheng, Low-temperature crystallization of sol-gel-derived lead zirconate titanate thin films using 2.45 GHz microwaves, Thin Solid Films 515 (2007) 2891-2896. 